\title{
EXAMINATION OF LOCAL ECONOMIC DEVELOPMENT AND POSSIBILITIES OF ARRANGEMENT FOR SELF-SUFFICIENCY
}

\author{
BERnAdetT SZabó, János Bana, LÁszló Posta, Ferenc BuZÁS \\ University of Debrecen, Faculty of Applied Economics and Rural Development \\ Böszörményi St. 138, 4032 Debrecen, Hungary \\ bszabo@agr.unideb.hu
}

\begin{abstract}
Local economic development (LED) is essential for realizing self-sufficiency and its continuous operation. Ecovillages are human-scale full-featured settlements of village- or city-typed, try to form a model for sustainable life form. Establishing ecovillages and similar initiatives may be the result of such an economic development conception. Basing on the example of Rozsály situated in the lagged behind Fehérgyarmat subregion the factors of LED, environmental consciousness and arrangement for self-sufficiency are detailed in this study. Regarding the four dimensions of ecovillages, Rozsály meets fully the requirement of the social/community and cultural/spiritual dimensions. The economic dimension is also developed, though there are several fields needed to be developed. Due to the ecological dimension Rozsály cannot be considered as an ecovillage, the denomination 'ecovillage initiative' is more appropriate. The village, however, started a good direction in order to break out from the problems typical to the area.
\end{abstract}

Keywords: local economic development, eco-village, sustainability, Rozsály

\section{INTRODUCTION}

In our study the chances of breakout from the aspects of local economic development (LED), environmental consciousness and arrangement for self-sufficiency are detailed by analyzing a given settlement. The place of our investigation is Rozsály located in the lagged behind Fehérgyarmat subregion in Szabolcs-Szatmár-Bereg county. The aim and the endeavor of the community are exemplary for the sake of maintenance not only in this region but even nationwide, dispite of the fact that migration and continuous decrease in population are typical to the other settlements in the subregion. The causes of its success, however, are not clear. According to certain sources, the success may be thanked to LED; others think that Rozsály may belong to ecovillages. It is indisputable that the realization of public employment and social economy is very successful in Rozsály. Our objectives are to reveal the concrete results of local economic development examining the social and economic conditions of the settlement relating to environmental consciousness; furthermore to investigate the arrangement for self-sufficiency in Rozsály along the four dimensions of ecovillages.

\section{MATERIAL AND METHOD}

Our results were strengthened by secondary and primary data gathering. The secondary data were collected from the local government of Rozsály, Hungarian Central Statistical Office, and Labour Centre of Northern Plain Region. The access of the majority of the data needed pre-arrangement and personal meeting. During primary data gathering qualitative research was carried out. The structured critical interview was chosen based on previously set questions in order to understand the cause and effect relationships better and to overview the processes in the community. We made critical interviews with the mayor of the settlement and the president of the Welfare Foundation in Rozsály in 2012. The aim of the critical interviews was to analyze the characteristics of the self-sufficient community, 
the factors of self-sufficiency, and to reveal the factors for successfully carrying out local economic development and arrangement for self-sufficiency for other communities having similar conditions.

\section{Basing the Chosen Topic by Reviewing the Most Relevant Literature}

In this chapter the most important literature sources are viewed and analyzed relating to local economic development and eco-villages.

Local economic development is essential for realizing self-sufficiency and its continuous operation. LED is a consciously directed intervention, which strives to improve the local economy and its processes and to make the economy sustainable (MEZEI, 2006). The aim of LED is to strengthen the economic basis of a local area to increase its economic future and the living standard for all. It is considered as a process by which population, enterprises and non-governmental sectors work together to establish better conditions for economic growth and employment generation (SWINBURN ET AL., 2006). Other purpose is to improve the productivity and competitiveness of local businesses, entrepreneurs and workers and to improve the quality of life of local population (BAJMÓCY, 2011). Each settlement has unique local conditions that either increase or reduce the chance for local economic development, and these conditions define the relative advantage of a community in its ability to attract, generate and retain investment (SWINBURN ET AL., 2006). Several methods and assets of LED are familiar such as community development, use of local money, introduction of money substituting tools, utilization of local renewable energy sources, and operation of social economy. The most effective way, however, is to use these methods in a jointly way.

The history of ecovillages dates back to $40-45$ years. The idea to establish such villages arose in the 1970'ies, and then similar initiatives appeared in several parts of the world independently from each other. Global Ecovillage Network (GEN) collects ecovillages and such initiatives. On the basis of GEN's definition ecovillages are communities in cities or in rural areas where local population strives to get the every-day things from the surrounding environment in a way that these activities should not be harmful to the environment (I1). Following the international examples, Hungarian Living Village Network was founded in Hungary (I2). The ecovillage movement appeared in Hungary at the beginning of the 1990'ies, since then there have been several domestic ecovillages and initiatives operating.

The operation of ecovillages may be successful by realizing their four dimensions such as social/community, cultural/spiritual, ecological and economic dimension and by basing on any combination of them.

$\checkmark$ On the basis of social/community dimension ecovillages are communities where population is responsible for those living around ensuring strong community cohesion (I3).

$\checkmark$ Cultural/spiritual dimension includes saving the Earth and every living creature, manifestation of cultural and artistic expression and spiritual diversity (I3).

$\checkmark$ From the aspect of ecological dimension ecovillages strongly belong to the surrounding natural environment, which ensures daily needs, food, clothes, shelter for them. Increasing proportion of the necessary foodstuffs is produced on the territory of the community by realizing ecological farming. Buildings and houses are built from local building materials focusing on passive houses and renewable energy sources. This way of life takes care of biodiversity as well (I3). Ecovillages strive to save the connection between people and nature as well as the universe (BATES, 2003). 
$\checkmark$ Regarding the economic dimension ecovillages are independent standing on their own feet and comparing to other local economies self-sufficiency is typical to them (BARTHA ET AL., 2011).

When examining the connections between ecovillages and local economic development the opinion arose by which the creation of ecovillages may be the result of an economic development conception. Several of the assets of local economic development appear in case of ecovillages as well (BANA, 2012), such as community development, development of local products, traditional economy, self-helping system, producing local alternative energy, creating social farms. The connections of the factors of ecovillages and local economic development were investigated in Rozsály.

\section{RESULTS}

In this chapter we detail the results relating to our research in Rozsály concerning especially the social and economic conditions of the village focusing on environmental consciousness and the factors for self-sufficiency and community cohesion. Finally Rozsály is investigated according to the four dimensions of ecovillages.

\section{Location and social conditions of Rozsály}

Rozsály is situated in the Northeastern part of Hungary, at the Eastern part of SzabolcsSzatmár-Bereg county, in Fehérgyarmat subregion, close to the Romanian and Ukraine border. Its distance from Nyiregyháza is 96 kilometres.

Rozsály has a population of 820 , its territory is 15 square kilometres, the population density is 55 persons per square kilometres. On the basis of its peripheral location and low population density, Rozsály may be considered as a real rural community. The biggest employer in the community is local government. The well-known Start labour program was firstly introduced in Fehárgyarmat subregion, and Rozsály is one of the most successful operators of the program nationwide.

A kindergarten and a primary school function in the settlement, which are maintained by the local government. The educational program of these institutes focuses outstandingly on evolving ecological view in children.

A local foundation has been operating the local TV, which helps strengthening community cohesion and information spreading among people. There has been a traditional folk group in Rozsály since 2009 functioning from different donations and subsidies. Its members sing folk songs and perform traditional folk dances bringing back the ancient's culture. The local foundation regularly organizes the Meeting of Ages, where young and old generations meet to hold joint programs such as cooking jam, baking bread. The aim is to vivify folk traditions for the youth, which only the elderly generation remember. This is the event which is used for strengthening even the civil relationships of the settlement.

Minority in Rozsály constitutes $26 \%$ of the population. The cooperation with the local gypsies has been exemplary since the change of the regime. Equality in the social land program has been always highlighted, thus gipsy families are continuously involved in the related activities.

There are several foundations and organizations in Rozsály, which helps in improving the social condition, such as the Local Foundation of Welfare for Rozsály, the Centre of Social Basic Service, Child Welfare and Family Support Service, Caring Centre and Social Bath. 


\section{Economic Conditions of Rozsály}

The major source of livelihood for the population is agriculture. 180 farmers and primary producers work in the community. The land quality is relatively weak. The ratio of agricultural land is extremely high, from which the proportion of arable land is outstanding. Production of cereals is typical to these areas. Wheat, corn, winter barley are dominant in the crop structure. Besides cereals, the area of orchards, such as apple and sour cherry is high in the village.

The local government's aim was to establish and realize self-sufficiency in the village by organizing a social farm. In 1992 the co-operative was ceased and 85 hectares remained in the property of the local-government. Self-sufficiency was the result of a planned activity. The management of the village firstly surveyed what and how much was necessary, and it was followed by the production. The already mentioned local foundation was created in 1993 by the local government. This foundation rents the majority of the land from the local government, which joined the social land program in 1993. Discounted rental service is available for the population living on agriculture. The machines are able to work in smaller sized parcels as well. The seed is for free for those in need. Within the social land program the animal keepers are also helped in storing and grinding the fodder.

Local government deals with animal husbandry as well. Earlier pigs were taken to families in the frame of the social farm, but this method did not work. Thus today local government keeps pigs of 60 to 70, which are slaughtered in the slaughterhouse owned by the local government. The maintenance of this slaughterhouse is extremely relevant as the next closest one locates in Fehérgyarmat. The produced products of plant and animal origin are mainly utilized by public catering; furthermore they are sold in the local social shop to local population at lower prices.

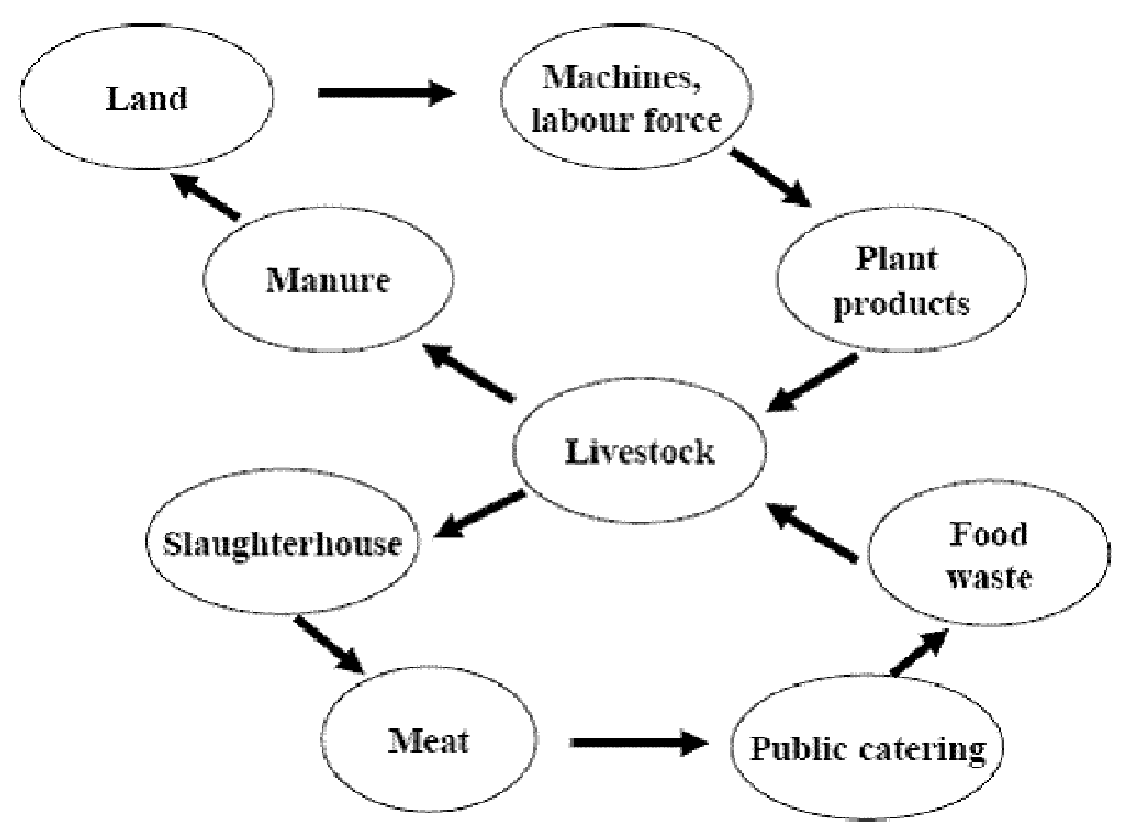

Figure 1. The cyclic progress of the social economy in Rozsály

Source: Local Government in Rozsály

There is a cyclic progress in Rozsály, which basis is the land (BANA, 2012). The cyclic progress contains the following elements (Figure 1): the local government owns the land, while the necessary machines and labour force are available in the village. The plant products are used in public catering, while fodders are fed with pigs. The manure is 
recycled into the soil ensuring the nutrient supply. Pork from the slaughterhouse is utilized in public catering and is sold to the population at a lower price. The food wastes are fed with the pigs getting into the cyclic process. This process is considered as a whole cycle from the aspect of the food, purchasing external resources and services is not necessary, by this self-sufficiency in Rozsály gets to a higher level.

The excess dependant on energy caused problems in the village, but local government started to solve this in a way that the cyclic process could become more complete. In order to prevent the illegal wood cutting because of the expensive gas local government ensures the household maintenance subsidy in the form of firewood. To reduce the energy dependence and to guarantee jobs for the population the village strives to utilize animal and human power instead of machines. In case of heating the building of the primary school is heated with by-products produced in the social farm, which may cause a reduction of $70 \%$ in heating costs. In order to produce sufficient quantity of raw material, an energy plantation of 7 hectares was established. Harvest happens by manpower, providing jobs for the local.

Industry does not play an important role in the economic life of Rozsály. Within the social farm concrete columns and paving stones are produced by public workers for own utilization and for sale. Regarding food industry production and process of local products are outstanding. Apple jam, plum jam, sour cherry jam and palinka are local products of the community. The operation of the local slaughterhouse is also an activity relating to the industry serving not commercial but social purposes. In connection with traditional jobs, the participation of gipsy population is relevant, as many of them deal with basketwork.

The commercial services evolved harmonizing with the requirements of the population. 13 commercial units are available in the village. The social shop has been operated by the Welfare Foundation of Rozsály since 2011. The goods of local farmers have priority when filling the stock of the shop. Farmers do not pay extra costs for the shop for selling their products. The shop sells these products, for example jam, honey, vegetable, fruit, handcraft products, to the population without price margin. Thank to the shop it is easier for the farmers to sell their products and it is cheaper for local people to purchase foodstuffs.

Tourism is not typical to Rozsály, though in several countries sustainability and tourism are connected to ensure the spread of sustainable way of life (HORVÁTH, 2009). Presently a rural cater house is under development. The owner and the would-be operator is the local government. The touristic attractions of the village involve the Greek-Catholic church ornamented with rare icons, the Reformed church and traditional folk house, the monument of János Maróthy in the Béke park and probably the biggest coat of arms of Kossuth in Hungary (I4).

The water supply is fully solved in the settlement. The public sewage network is 8,5 kilometer long, which means that sewage network of 900 meter goes with one kilometer water pipe. Waste management is organized in Rozsály, just like the selective waste collection. The electricity is present almost in every household $(99 \%)$. The ratio of gas supply is $72 \%$ in the settlement. Approximately $30 \%$ of the households heat with gas, $40 \%$ carry out mixed heating, the remaining part of the families heat with wood. There is a tendency in Rozsály that is more and more households convert into wood heating.

\section{Investigation of Rozsály regarding the four dimensions of ecovillages}

The social/community dimension of ecovillages realizes fully in Rozsály. Local government focuses on supporting and helping families in socially lagged behind situation and an extra foundation was established with this purposes. The residents form a real community.

The cultural/spiritual dimension appears in the life of the village as well. The residents work together for their development, save their traditions together and jointly organize programs, 
events and celebrate memorable holidays. The local population understood the fact that the elements of life on Earth and the place of residents for living belong together, they depend on each other, and people realized that the land is the basis for everything for existence.

The realization of ecological-natural dimension may be considered as the most critical in Rozsály. Though education for environmental consciousness begins in primary school and farmers try to introduce environmental friendly methods when operating the social farm, the primary aspects are self-sufficiency and job creation in the village while in ecovillages these are the environmental protection and saving the natural values. Furthermore, the majority of the produced products must be bio-products in ecovillages, which does not realize fully in Rozsály. When building houses local raw materials are used in ecovillages by utilizing environmental friendly materials. In Rozsály being an already existing village the houses were built mainly from bricks and clay. The attitude towards using renewable energy sources, however, is much better. The change-over of public institutes for utilizing alternative energy sources has already begun. Selective waste collection operates in an organized way in the village. The major part of the population carries out composting which contributes to strengthening the ecological dimension. Saving biodiversity appears in the form of Natura 2000 territories.

Regarding the economic dimension Rozsály has started an exemplary work, and the social farm formed by local people meets the requirement and concepts of ecovillages. Relating to food supply the village achieves self-sufficiency in a higher and higher level and strives to use alternative energy sources in case of energy utilization thus reducing the energetic dependence. Processing raw materials and generating added value are typical in the village. Retaining money in Rozsály and preventing it from leaving the village is advantageous in case of food goods. There are problems in the service sector as the owners of enterprises dealing with different services are residents of other settlements. From the economic aspect the excess dependence of the village on external sources may be considered as another problem.

\section{CONCLUSIONS}

On the basis of the results, our conclusion is the fact that Rozsály has started a good direction in order to break out from the problems concerning the area and may be exemplary for other subregions being under similar unfavourable social and economic conditions such as for the Hódmezővásárhely subregion, where decreasing and aging population and unfavourable vitality tendency are major problems (HORVÁTH AND BODNÁR, 2009). In our opinion contrary to several approaches citing Rozsály as an ecovillage the village does not meet strictly the requirements of ecovillages in every aspect. It is better to use the phrase 'ecovillage initiative' for Rozsály. Mostly local economic development appears in the village, but the residents and the management of the settlement strive to focus on even ecological aspects as well.

In order to realize the ecological dimension fully, the objective of every resident should be even the protection of natural values and biodiversity besides ensuring their own livelihood. Naturally the results are exemplary and if every settlement followed this direction it would contribute to the global ecological footprint of appropriate size.

Unemployment is the central problem of the settlement which is caused by the narrow possibilities of higher qualified people, the lack of market of local products, the underdeveloped tourism and the less number of enterprises run by local residents. One of the chances of the village is to realize the ecological factors in a more highlighted way and the settlement would meet the criteria of ecovillages. But this is the less real opportunity. Another chance is starting the connection with Satu Mare, which may help in reaching 
higher level of employment and ensuring market for products. In this case Rozsály may be relatively independent and ecological aspects may be further improved by using higher ratio of renewable energy sources.

It would be practical to start public transportation between Rozsály and Satu Mare which may result in decreasing the number of the unemployed and in improving the possibilities of people of higher qualification. In order to build cross-border cooperation it is necessary to make the communication more successful. For this purpose it would be useful to educate Romanian and Ukraine languages in primary school or even for adults. In order to make selling of products of animal origin easier a vacuum packing machine would be essential. By renewing the cross-border cooperation the development of tourism may be possible, which is already realized by the local government as a rural catering house is under construction. This ensures further possibilities as tourists may purchase local products and may spread its fame. In order to expand the marketing of local products the House of Szatmár Favours is established. The most important thing, however, is to maintain the achieved results and one must focus on the fact that under such conditions the settlement may only survive which is populated by real community.

\section{REFERENCES}

BAJMÓCY Z. (2011): Bevezetés a helyi gazdaságfejlesztésbe. Jate Press, Szeged, pp. 15-26. BANA J. (2012): Rozsály - ahol minden a f(F?)öld körül forog. Diplomadolgozat. Debreceni Egyetem AGTC GVK, Debrecen, 2012. 99 p.

BARTHA A., DVORZSÁK J., GYUlOVICS I., SZÁNTAY Zs. (2011): „Az ökofalvak a társadalmi megújulás kísérletező központjai” - avagy rövid összefoglalás egy Ökofalucsíra kezdeményezésről. Budapest, 7 p.

BATES, A. (2003): Ecovillage Roots (and Branshes) issue \#117 „Ecovillages - What Have We Learned?" in: Communities Magazien (online), http://gen.ecovillage.org/iservices/publications/articles/CM117RootsandBranches.pdf HoRVÁTH J. (2009): Az ökológiai turizmus gyakorlata. In: Falusi turizmus Norvégiában és Izlandon. Szerk.: Bodnár K. - Horváth J. Szegedi Tudományegyetem, Mezőgazdasági Kar, Hódmezővásárhely, 2009, pp. 64-72.

HORVÁTH J., BODNÁR K. (2009): Vidékfejlesztési lehetőségek Kakasszéken és környékén. Jelenkori Társadalmi és Gazdasági Folyamatok 4(3-4): 26-30.

MEZEI C. 2006 : A települési önkormányzatok szerepe a helyi gazdaság fejlesztésében, Pécs, $26 \mathrm{p}$.

Swinburn, G., Goga, S., Murphy, F. (2006): Local Economic Development - A Primer Developing and Implementing Local Economic Development Strategies and Action Plans. World Bank, 2006. 86 p.

I1: http://gen.ecovillage.org/ecovillages/whatisanecovillage.html

I2: http://www.harmonet.hu/kultura_utazas/20583-okofalvak-elofalvakmagyarorszagon.html

I3: http://gen.ecovillage.org/ecovillages/4pillarsofsustainability.html

I4: http://www.rozsaly.hu/ 